\title{
Percutaneous Biopsy of Kidney
}

National Cancer Institute

\section{Source}

National Cancer Institute. Percutaneous Biopsy of Kidney. NCI Thesaurus. Code C51901.

Removal of tissue from the kidney, for microscopic examination, obtained

percutaneously. 